\title{
Assessment of the Effects of Four Plant Species Used in Mexican Traditional Medicine Against Microcystis aeruginosa
}

René Solano Jiménez ( $\nabla$ ibq.rene.solano@hotmail.com )

Instituto Mexicano de Tecnología del Agua: Instituto Mexicano de Tecnologia del Agua https://orcid.org/0000-0002-2305-0815

\section{Sofia Esperanza Garrido Hoyos}

Mexican Institute of Water Technology: Instituto Mexicano de Tecnologia del Agua

Ana María Sandoval Villasana

Mexican Institute of Water Technology: Instituto Mexicano de Tecnologia del Agua

Maria Luisa Villareal

Universidad Autónoma del Estado de Morelos Centro de Investigación en Biotecnología: Universidad Autonoma del Estado de Morelos Centro de Investigacion en Biotecnologia

José Roberto Villagómez Ibarra

Universidad Autonoma del Estado de Hidalgo - Instituto de Ciencias Básicas e Ingeniería

\section{Research Article}

Keywords: Anti-algal activity, algaecide, algistatic effect, crude extracts, cyanobacterial blooms, herbal medicine plants, inhibition mechanisms, Microcystis aeruginosa

Posted Date: July 23rd, 2021

DOI: https://doi.org/10.21203/rs.3.rs-628419/v1

License: (9) (1) This work is licensed under a Creative Commons Attribution 4.0 International License. Read Full License 


\section{Abstract}

Microcystis aeruginosa is one of the main harmful bloom-forming cyanobacteria species worldwide. Plant extracts are considered an appropriate practice to obtain effective, economical and sustainable algaecides. For the first time, the effects of Argemone mexicana, Bougainvillea spectabilis, Larrea tridentata and Tradescantia zebrina on the growth of $M$. aeruginosa in solid and liquid media were investigated by measuring cell density, Chl-a concentration, malondialdehyde (MDA), proteins and nucleotides. Total polyphenol content was quantified to reveal the nature of inhibition. The results in solid medium showed that the methanolic extract of $L$. tridentata had the greatest effect, showing an inhibition zone of $28.67 \pm 0.58 \mathrm{~mm}$. In liquid medium, the methanolic extract of L. tridentata again showed the greatest effects on the cell density of $M$. aeruginosa $(93.80 \%, p<0.0001)$, followed by $B$. spectabilis $(87.66 \%, \mathrm{p}<0.0001)$ and $A$. mexicana with $(87.11 \%, \mathrm{p}<0.001)$, with $\mathrm{EC}_{50}=13.63,20.27$ and $24.47 \mathrm{mg} / \mathrm{L}$, respectively. L. tridentata also showed a decrease of Chl-a of 91.51\% ( $\mathrm{P}<0.0001)$, MDA increased 6.42 times, and proteins and nucleotides 2.09 and 2.12 times in relation to the control, respectively. $L$. tridentata showed the highest total polyphenol content, $363.51 \mathrm{mgGAEq} / \mathrm{gDE}$. These results indicate that the decrease in photosynthetic capacity and lipid peroxidation are the most probable mechanisms of action of this species against $M$. aeruginosa.

\section{Introduction}

Cyanobacterial blooms in eutrophic lakes are a global problem that has been intensifying since the last few decades (Huisman et al., 2018). Recent studies on cyanobacterial abundance and hydroclimatic changes over the past millennium show that cyanobacterial abundance has been significantly higher in warmer periods, including the current warm period (1900-present), and may continue to increase in coming years in subtropical water bodies as a consequence of global warming (Yan et al., 2020).

Recent research has focused on the development of plant-derived algaecides for the control of cyanobacterial blooms. There is evidence that extracts from a wide range of aquatic macrophyte species possess inhibitory effects on cyanobacteria, such as extracts from Ceratophyllum demersum and Potamogeton pectinatus (Ghobrial et al., 2015; Wang et al., 2015), Potamogeton cristatus, Potamogeton maackianus, Potamogeton lucens, Vallisneria spinulosa and Hydrilla verticillata (Wang et al., 2015), which are highly harmful to M. aeruginosa and Oscillatoria tenuis. Even some species such as Lemna trisulca besides inhibiting the growth of Anabaena flos-aquae, also degrades its neurotoxin, anatoxin-a (Kaminski et al., 2014; Kaminski et al., 2015).

Medicinal plants have long been used in mexican traditional medicine, and there is increasing research on the use of plants to control algal growth, but the available information on the use of Mexican medicinal plants for the control of $M$. aeruginosa is practically nil. However, it has been observed that species such as Achillea ageratum L. and Origanum compactum (Tebaa et al., 2017), Dracontomelon duperreanum (Wang et al., 2016) and some compounds such as the terpenoid artemisinin from Artemisia annua (Ni et al., 2012); ginkgolic acids present in Ginkgo biloba (Zhang et al., 2013a), neo-przewaquinone 
A isolated from Salvia miltiorrhiza (Zhang et al., 2013b), have shown potent effect on M. aeruginosa. Currently, allelochemicals with anti-cyanobacterial activity identified include, phenolic acids, fatty acids, tannic acid, lactones, terpenoids, alkaloids, flavonoids and sulfides (Tan et al., 2019).

The objective of this study was to evaluate the algicidal effects of four species used in mexican traditional medicine, A. mexicana, B. spectabilis, L. tridentata and T. zebrina, on the toxic bloom-forming cyanobacterium $M$. aeruginosa and to identify possible mechanisms of action, focusing the experiments on (i) growth inhibition on solid agar and (ii) growth inhibition in liquid medium, effects on Chl-a, MDA, protein and nucleotide content.

\section{Materials And Methods}

\section{Plant material}

In our study, 4 plant species used in mexican traditional medicine were selected for their availability in accessible areas and for their antibacterial activities. The species were collected between December 2018 and March 2019, in different localities of the Mexican Republic and identified in the HUMO herbarium of the Biodiversity and Conservation Research Center (CIByC) of the Autonomous University of the State of Morelos (UAEM), generating a folio number for each species (Table 1). All species were washed with tap water and then rinsed with distilled water to remove debris and dried at room temperature. Subsequently, the plants were pulverized separately to use their powder in the extraction process.

Table 1 Geographic location of plant species collected in Mexico

\begin{tabular}{|llll|}
\hline Species & Location & Geographical location & HUMO Foil \\
\hline A. mexicana L. & Cuauchichinola, Morelos & $18.893975,-99.168232$ & 38871 \\
\hline B. spectabilis Willd. & Jiutepec, Morelos & $22.153655,-100.886267$ & 38872 \\
\hline L. tridentata (DC.) Coville. & Los Gómez, San Luis Potosí & $18.670007,-99.375895$ & 38873 \\
\hline T. zebrina Bosse. & Jiutepec, Morelos & $18.884940,-99.160087$ & 38874 \\
\hline
\end{tabular}

\section{Preparation of extracts}

Half of each powdered plant was mixed with $6 \mathrm{~L}$ of absolute ethyl alcohol (99.5\%, Sigma-Aldrich) and absolute methyl alcohol (99.8\%, Sigma-Aldrich), respectively, and left to macerate for 7 days at room temperature $\left(25-29^{\circ} \mathrm{C}\right)$. The supernatants were filtered under reduced pressure to remove plant material through Whatman No. 1 paper (pore size $11 \mu \mathrm{m}$ ) and concentrated on a rotary evaporator at $39-40^{\circ} \mathrm{C}$. Concentrated liquid extracts were transferred to glass vials and frozen at $-80^{\circ} \mathrm{C}$ for freeze-drying. All extracts were stored refrigerated $\left(4^{\circ} \mathrm{C} \pm 0.1\right)$ until use. Table 2 shows the yields of the extracts of the plant species used in this study.

Table 2 Yields of ethanolic and methanolic extracts of different plant species 


\begin{tabular}{|llllll|}
\hline Species & Disolvent & Plant quantity $(\mathrm{g})$ & Moist extract $(\mathrm{mL})$ & $\begin{array}{l}\text { Dried extract } \\
(\mathrm{g})\end{array}$ & Yield (\%) \\
\hline \multirow{2}{*}{ A. mexicana } & Ethanol & 640 & 70 & 37.93 & 5.92 \\
& Methanol & 640 & 140 & 80.56 & 12.58 \\
\hline \multirow{2}{*}{ B. spectabilis } & Ethanol & 320 & 280 & 20.76 & 6.48 \\
& Methanol & 320 & 280 & 50.28 & 15.71 \\
\hline \multirow{2}{*}{ L. tridentata } & Ethanol & 1,470 & 385 & 166.02 & 11.29 \\
& Methanol & 1,470 & 420 & 241.21 & 16.40 \\
\hline \multirow{2}{*}{ T. zebrina } & Ethanol & 150 & 105 & 5.11 & 3.40 \\
& Methanol & 150 & 140 & 17.58 & 11.72 \\
\hline
\end{tabular}

\section{Determination of total polyphenols}

The concentration of total polyphenolic compounds in the extracts was determined using the FolinCiocalteu method. A standard curve of gallic acid (with concentrations of $0,1,2.5,5,7.5,10,11,12,13$, $14,15,16,17,18,19$ and $20 \mathrm{mg} / \mathrm{L}$ ) was prepared and the equation $\mathrm{y}=0.1186 \mathrm{x}+0.0077$ with a coefficient of determination $\left(R^{2}=0.9961\right)$ was obtained. Subsequently, $2 \mathrm{mg}$ of each extract was suspended in $3 \mathrm{~mL}$ of methanol and brought to $10 \mathrm{~mL}$ with distilled water. Next, $500 \mu \mathrm{L}$ of each of these solutions were taken and mixed with $250 \mu \mathrm{L}$ of F-C $1 \mathrm{~N}$ reagent (Sigma-Aldrich), shaken for 5 min and 1,250 $\mu \mathrm{L}$ of $20 \% \mathrm{Na}_{2} \mathrm{CO}_{3}$ (J. T. Baker) was added. The samples were allowed to stand for $2 \mathrm{~h}$ and absorbances were measured at $760 \mathrm{~nm}$ using the UV-Vis 1800 spectrophotometer (Shimadzu). The values of $\mathrm{x}$ in the above equation were substituted for the values of the absorbances obtained and the results were recorded as mg gallic acid equivalent/g dry extract (mgGAEq/gDE).

\section{Cyanobacteria cultivation}

The cyanobacterial species $M$. aeruginosa was provided by the Bacteriology Laboratory of the FES-I (Facultad de Estudios Superiores Iztacala) of UNAM (Universidad Nacional Autónoma de México). M. aeruginosa was grown in BG-11 medium, with a light intensity of $57 \mu \mathrm{mol}$ photons $\mathrm{m}^{-2} \mathrm{~s}^{-1}$, at $28 \pm 1^{\circ} \mathrm{C}$ and with a 12:12 hour light:dark photoperiod. The culture was shaken three times daily for 2 weeks and was used when $M$. aeruginosa reached the exponential growth phase, which was determined by measuring cell density every day for 18 days.

\section{Evaluation of algaecidal effects in solid medium}

To evaluate the inhibitory effects of ethanolic and methanolic extracts of the plant species, the procedure established by Zerrifi et al., 2019, with some modifications, was followed. The algaecidal activity of the extracts was evaluated using the agar diffusion technique in Petri dishes. $50 \mathrm{mg}$ of each extract was resuspended in $1 \mathrm{~mL}$ of methanol. Filter paper discs (Whatman No. 1) of $9 \mathrm{~mm}$ diameter were 
impregnated with 20,60 and $100 \mu \mathrm{L}(1,3$ and $5 \mathrm{mg}$ ) of the different extracts, copper sulfate (J. T. Baker) and methanol impregnated discs were also used as positive and negative controls and air dried. The discs were placed on BG11 medium with $3 \%$ bacteriological agar and $500 \mu \mathrm{L}$ of previously inoculated $M$. aeruginosa. All plates were sealed with parafilm and exposed to the same $M$. aeruginosa culture conditions as above. Inhibitory effects were measured by the diameter value of the inhibition zone after 9 days of $M$. aeruginosa growth.

\section{Measurements of cell density}

To analyze the concentration-dependent effects of the methanolic plant extracts on the growth of $M$. aeruginosa, the different initial concentrations of extracts were used. $3 \mathrm{~mL}$ of the exponentially growing M. aeruginosa culture was inoculated into $250 \mathrm{~mL}$ flasks and $100 \mathrm{~mL}$ of BG-11 and allowed to acclimate for 7 days. Various doses of solution of each extract (previously resuspended in $0.2 \%$ dimethyl sulfoxide) were added to the cultures to obtain final concentrations of $10,25,50,50$ and $75 \mathrm{mg} / \mathrm{L}$. The initial density of $M$. aeruginosa was approximately $1 \times 10^{6}$ cells $/ \mathrm{mL}$. Cultures were allowed to grow for 12 days under the same conditions as described above. No extract was added to the control groups and each experiment included treatments in triplicate. At two-day intervals, $M$. aeruginosa growth was monitored by counting cells with an optical microscope and a hemocytometer. The inhibition ratio (IR) was used for expressing the effects of the extracts, which was defined as follows:

$$
\operatorname{IR}(\%)=\left(1-\frac{T}{C}\right) \times 100
$$

Where $\mathrm{T}$ and $\mathrm{C}$ refer to cell density of treatment and control, respectively.

\section{Effective concentration 50 (CE50)}

The $50 \%$ effective concentration $\left(\mathrm{EC}_{50}\right)$ defined as the concentration at which the IR is $50 \%$ on the inhibition curve, was calculated at 12-days and based on the cell density using linear interpolation analysis.

\section{Quantification of Chl-a}

Based on the results obtained in the previous sections (see Results), the L. tridentata extract was selected for further analysis of its mechanisms of action on M. aeruginosa. Chlorophyll-a concentration [Chl-a] was measured using UV-Vis 1800 spectrophotometer (Shimadzu) and calculated with reference to the standard method described by Hein (2017). An appropriate volume of each culture was passed through a glass fiber filter under reduced pressure, the filters were recovered and $10 \mathrm{~mL}$ of $90 \%$ acetone was added. Samples were triturated with a tissue homogenizer and stored in the dark for $24 \mathrm{~h}$ at $4{ }^{\circ} \mathrm{C}$. The samples were then centrifuged for $20 \mathrm{~min}$ at $3000 \mathrm{rpm}$, the supernatants were measured at 664 and $750 \mathrm{~nm}$, acidified with $0.1 \mathrm{~mL}$ of $0.1 \mathrm{~N} \mathrm{HCl}(36.6-38 \%, \mathrm{~J}$. T. Baker), allowed to react for $90 \mathrm{~s}$ and measured again at 
absorbances 665 and $750 \mathrm{~nm}$. The Chl-a concentration $\left(\mathrm{mg} / \mathrm{m}^{3}\right)$ was calculated according to the following equation:

$$
[\mathrm{Chl} \mathrm{a}]=\frac{26.7\left(664_{\mathrm{b}}-665_{\mathrm{a}}\right) \times \mathrm{V}_{1}}{\mathrm{~V}_{2} \times \mathrm{L}}
$$

where $664_{b}$ and $665_{a}$ : values of the absorbances before and after acidification, $V_{1}$ : volume of the extract in liters, $\mathrm{V}_{2}$ : volume of the sample in $\mathrm{m}^{3}$ and $\mathrm{L}$ : light path in the cuvette in $\mathrm{cm}$. The results were transformed to $\mathrm{mg} / \mathrm{L}$.

\section{Lipid peroxidation}

Lipid peroxidation was reflected in terms of malondialdehyde MDA concentration [MDA] in cells and was determined according to the work of $\mathrm{Li}$ et al (2016), with slight modifications. Appropriate volumes of each sample were collected and centrifuged at 4,000 rpm for $10 \mathrm{~min}$. The supernatant was carefully removed, the cell pellets were resuspended with $5 \mathrm{~mL}$ of $10 \%(\mathrm{w} / \mathrm{v})$ trichloroacetic acid ( $\geq 99 \%$, Sigma Aldrich) and centrifuged at 12,000 rpm for $10 \mathrm{~min}$. Then, $2 \mathrm{~mL}$ of the supernatant was mixed with $2 \mathrm{~mL}$ of $0.6 \%$ thiobarbituric acid ( $\geq 98 \%$, Sigma Aldrich) (in $10 \%$ trichloroacetic acid solution) and incubated in water at $95{ }^{\circ} \mathrm{C}$ for $30 \mathrm{~min}$. Samples were cooled in water at room temperature and centrifuged again at $12,000 \mathrm{rpm}$ for $10 \mathrm{~min}$. The absorbances of the supernatants were measured at 532, 600 and $450 \mathrm{~nm}$, taking as blank a mixture of $2 \mathrm{~mL}$ ultrapure water and $2 \mathrm{~mL} 0.6 \%$ thiobarbituric acid. The MDA level $(\mu \mathrm{mol} / \mathrm{L})$ was calculated according to eq:

$$
[\mathrm{MDA}]=6.45 \times\left(\mathrm{OD}_{532}-\mathrm{OD}_{600}\right)-0.56-\mathrm{OD}_{450}
$$

\section{Quantification of proteins and nucleotides}

Proteins and nucleotides have been documented to have strong UV absorption at 280 and $260 \mathrm{~nm}$, respectively, and can be easily detected using a UV-Vis spectrophotometer. This method is widely used to determine membrane integrity. Five $\mathrm{mL}$ of $M$. aeruginosa culture treated with different concentrations of L. tridentata were taken and filtered with $0.22 \mu \mathrm{m}$ Millipore filter to remove cell biomass. The supernatants were measured at 260 and $280 \mathrm{~nm}$ using the UV-Vis 1800 spectrophotometer (Shimadzu). The OD ratio between the experimental group and the control group was used to evaluate the level of protein and nucleotide release (Zhang et al., 2012).

\section{Statistical analysis}

Analyses of the data were performed using GraphPad Prism 8.0.1 software. All experiments were performed in three replicates. Means and standard deviation (SD) were calculated and presented. Data from different treatments were compared to the control, to determine statistical significance using the 
ANOVA test and Tukey test. Differences were considered to be significant at $p<0.05(*), p<0.01\left({ }^{\star *}\right)$, $p<0.001(\star \star \star)$ and $p<0.0001(\star \star \star \star)$.

\section{Results}

\section{Concentration of total polyphenols in the extracts}

The results of total polyphenol quantification of ethanolic and methanolic plant extracts expressed in $\mathrm{mg}$ gallic acid equivalents/g dry extract (mgGAEq/gDE) are presented in Fig. 1. L. tridentata presented the highest concentrations $(266.49 \pm 12.29,363.51 \pm 13.63$, respectively). In A. mexicana the concentrations were $112.97 \pm 15.41$ and $150.60 \pm 24.21$. B. spectabilis showed slightly lower concentrations, $99.26 \pm 4.17$ and $100.67 \pm 7.72$. The ethanolic and methanolic extracts of $T$. zebrina showed the lowest concentrations, $33.18 \pm 0.72$ and $52.48 \pm 0.57$, respectively.

\section{Algaecide tests on solid agar}

After 9 days of growth, inhibition halos were measured and the results obtained are presented in Fig. 2a and $b$. All methanolic extracts were slightly more effective than ethanolic extracts. The most important effects were observed with the methanolic extract of $L$. tridentata, with $5 \mathrm{mg}$ presented an inhibition zone of $28.67 \pm 0.58 \mathrm{~mm}(\mathrm{p}<0.0001)$. The methanolic extracts of $A$. mexicana and $B$. spectabilis exhibited similar results in the three concentrations analyzed, with $5 \mathrm{mg}$, showed inhibition halos of $20.33 \pm 1.53$ and $21.00 \pm 1.00 \mathrm{~mm}(p<0.0001)$, respectively. The smallest effects were observed with $T$. zebrina, with an average inhibition of $12.00 \pm 1.00 \mathrm{~mm}(\mathrm{p}<0.001)$ with $5 \mathrm{mg}$. Methanol used as a negative control showed no effect, while $\mathrm{CuSO}_{4}$ presented the greatest algaecidal effect, $42.00 \pm 1.00 \mathrm{~mm}(p<0.0001)$.

\section{Effects of methanolic extracts on the growth of $M$. aeruginosa}

The results of growth inhibition of $M$. aeruginosa in liquid medium are presented in Fig. 3 and 4 . $L$. tridentata recorded the highest inhibitory effects: from day 8, a significant decrease in the cell density of $M$. aeruginosa was observed in the four treatments $(10,25,50$ and $75 \mathrm{mg} / \mathrm{L})$, reaching inhibitions of 44.96\% ( $p<0.01), 55.83 \%(p<0.001), 68.66 \%(p<0.01)$ and $81.10 \%(p<0.001)$. By day 10 , the inhibitions recorded were $29.69 \%(p<0.05), 62.19 \%, 76.48$ and $87.52 \%$ ( $p<0.001)$. However, the greatest effects were obtained on day 12 , where cell densities were $5.411,2.656,1.509$ and $0.563 \times 10^{6}$ cells $/ \mathrm{mL}$, with inhibitions of $40.45 \%(p<0.01), 70.77 \%, 83.39$ and $93.80 \%(p<0.0001)$, with respect to the control. In descending order, $B$. spectabilis and $A$ mexicana presented similar results. In the $B$. spectabilis group, on day 12 at 10, 25, 50 and $75 \mathrm{mg} / \mathrm{L}$, cell densities were 5.367, 4.071, 1.854 and $1.097 \times 10^{6} \mathrm{cell} / \mathrm{s} / \mathrm{mL}$, with inhibitions of $39.63 \%(p<0.01), 54.20 \%(p<0.05), 79.14(p<0.001)$ and $87.66 \%(p<0.0001)$. As for the group studied with $A$ mexicana, the treatments with 50 and $75 \mathrm{mg} / \mathrm{L}$, showed a clear decrease in cell density from day 6 and until the end of the experiment, where the cell densities were 1.214 and $1.066 \times 10^{6}$ cells $/ \mathrm{mL}$, with inhibitions of $85.57 \%$ and $87.33 \%$, in relation to the control $(\mathrm{p}<0.001)$. The lowest effects were presented with $T$. zebrina, since no concentration exceeded $25 \%$ inhibition, only significant inhibition 
was recorded at $50 \mathrm{mg} / \mathrm{L}$ on day 10 and at $75 \mathrm{mg} / \mathrm{L}$ on day 12 , where cell densities were 5.536 and $6.783 \times 10^{6}$ cells $/ \mathrm{mL}$, reaching inhibitions of 18.68 and $20.94 \%$ in relation to the control $(p<0.05)$.

\section{Effective concentration $50\left(\mathrm{EC}_{50}\right)$}

Based on the results of the growth inhibition tests of $M$. aeruginosa in liquid medium, the extracts of $A$. mexicana, $B$. spectabilis and $L$. tridentata were chosen to calculate their $\mathrm{EC}_{50,12 \mathrm{~d}}$ and evaluate their anticyanobacterial efficacy. The lowest value was obtained with the extract of $L$. tridentata with a value of $13.63 \mathrm{mg} / \mathrm{L}$, followed by the extract of $B$. spectabilis with $20.27 \mathrm{mg} / \mathrm{L}$ and $A$. mexicana with $24.47 \mathrm{mg} / \mathrm{L}$.

\section{Effects of $L$. tridentata on the content of Chl-a, MDA, nucleotides and proteins in $M$. aeruginosa}

Based on the results of the $\mathrm{EC}_{50,12 \mathrm{~d}}$, the methanolic extract of $L$. tridentata was selected to study its effects on the photosynthetic activity of expressed as Chl-a concentration [Chl-a], lipid peroxidation [MDA] and on the leakage of intracellular material (nucleotides and proteins) in $M$. aeruginosa. The results obtained are shown in Fig. 5. In Fig. $5 \mathrm{a}$ it can be seen that [Chl-a] in M. aeruginosa was significantly affected with increasing concentration and with exposure time to L. tridentata. In the control group, [Chl-a] showed a significant increase with prolongation of time, reaching a [Chl-a] $=3.029 \mathrm{mg} / \mathrm{L}$ at day 12 . Compared to the control, all treatment groups showed a significant decrease in [Chl-a] from day 8. Particularly, at concentrations of 50 and $75 \mathrm{mg} / \mathrm{L}$, [Chl-a] decreased from day 2 to the end of the experiment, where [Chl-a] $=0.544$ and $0.257 \mathrm{mg} / \mathrm{L}$ were quantified, which meant decreases of $82.04 \%$ and $91.51 \%$, with respect to the control $(p<0.0001)$.

As shown in Fig. 5b, [MDA] in $M$. aeruginosa visibly increased as concentration increased and exposure time extended. The control group showed no significant change in [MDA] throughout the experiment. After 2 days of exposure, only a significant increase in [MDA] was observed at $75 \mathrm{mg} / \mathrm{L}(\mathrm{p}<0.05)$. From day 8, [MDA] increased significantly at all concentrations of $L$. tridentata, with the exception of day 10 at $10 \mathrm{mg} / \mathrm{L}$. However, it was at day 12 where the greatest effects were observed, since at 25, 50 and 75 $\mathrm{mg} / \mathrm{L}[\mathrm{MDA}]=4.42,5.82$ and $6.61 \mu \mathrm{mol} / \mathrm{g}$ protein were quantified, which translated into 4.3-, 5.65- and 6.42 -fold increases compared to the control ( $p<0.001, p<0.001$ and $p<0.0001$, respectively).

Figs. $5 c$ and $5 d$ show nucleotide and protein leakage as a probable consequence of lipid peroxidation of $M$. aeruginosa cells caused by prolonged exposure to $L$. tridentata extract. The control groups showed no significant change in $\mathrm{OD}_{260}$ and $\mathrm{OD}_{280}$ values throughout the experiment. From day $4, L$. tridentata induced a gradual concentration-dependent increase in $\mathrm{DO}_{260}$ and $\mathrm{DO}_{280}$ values. By day $12, \mathrm{DO}_{260}$ values of 1.87 and 2.13 , respectively, were quantified in the groups treated with 50 and $75 \mathrm{mg} / \mathrm{L} \mathrm{L}$. tridentata. For $\mathrm{DO}_{280}$ under the same conditions, the values were 1.89 and 2.22 , respectively. These values were significantly higher compared to their control groups $(p<0.01)$. These results together with those of MDA, indicate that, without any doubt, the extract of $L$. tridentata, provoked a very severe lipid peroxidation in the cells of $\mathrm{M}$. aeruginosa. 


\section{Discussion}

In Mexico, medicinal plants have been used since pre-Hispanic times and it is estimated that, of the 30,000 recorded plant species, approximately 3,000 to 5,000 are of medicinal use and 75 species have shown antibacterial activity (Villaseñor et al., 2016; Palma et al., 2017). Phytochemical analysis in $A$. mexicana and $B$. spectabilis reveal that leaves, stems and flowers are rich in phenolic acids, tannins, flavonoids, terpenoids, alkaloids. They possess antibacterial activity against $9 \mathrm{Gram}(+)$ and $9 \mathrm{Gram}(-)$ and 8 Gram(+) and 13 Gram(-) bacteria, respectively (Brahmachari et al., 2013; Ghogar et al., 2016; Abarca and Petricevich, 2018). L. tridentata is widely distributed in the arid zones of northern Mexico and can survive under extreme conditions of drought and frost. In addition, mainly due to its extensive range of allelopathic substances and secondary metabolites, it is one of the dominant species in the desert microphytic scrub community, displacing other species typical of this ecosystem, hence its common name "gobernadora" (Mata et al., 2018). More than 20 flavonoid aglycones, phenolic lignans, alkaloids, alkaloids, terpenoids and fatty acids have been identified in the leaves and stems of L. tridentata (Arteaga et al., 2005). T. zebrina leaves exhibit a high content of phenolic compounds, tannins and flavonoids and possess activity against $6 \mathrm{Gram}(+)$ and $2 \mathrm{Gram}(-)$ bacteria (Tan et al., 2014). The presence of these compounds and reports of their antibacterial activity, make extracts of these species good candidates for algaecidal agents.

In solid medium tests, the methanolic extracts of the four species showed the highest inhibitory effects, despite the fact that, in the case of T. zebrina, the ethanolic extract presented a higher polyphenolic content. These results suggest that methanolic extracts may possess other families of algaecidal compounds in addition to polyphenols, which act synergistically in the inhibition process. The methanolic extracts of $A$. mexicana, $B$. spectabilis and $L$. tridentata showed the greatest effects, causing inhibition zones of 20.33, 21.00 and $28.67 \mathrm{~mm}$. Our results are similar to those reported by Zerrifi et al., 2019, when they observed that extracts of Laurencia pinnatifida and Bornetia secundiflora generated inhibition zones of $17.33 \pm 0.33$ and $27.33 \pm 0.33 \mathrm{~mm}$ in $M$. aeruginosa culture after 7 days of growth.

In liquid medium, methanolic extracts of the four plant species possess statistically significant algaecidal activity against the toxic cyanobacterium $M$. aeruginosa. These results are similar to values obtained in some works such as that of Shi et al. 2020, where they analyzed the effects of ten plant species on the growth of Microcystis flos-aquae, reporting that all species showed significant inhibitory effects, with Alternanthera philoxeroides showing the highest degree of inhibition (77.30\%), after 4 days of exposure to a concentration of $3 \mathrm{~g} / \mathrm{L}$. In another study published by Tazart et al., 2018, they observed that, aqueous extracts of Ranunculus aquatilis and Nasturtium officinale showed inhibitions of 100 and $75 \%$ in $M$. aeruginosa positively correlating the polyphenols, flavonoids and total tannins levels and the degree of inhibition of these species, similar to what was observed in our research with extracts of $A$. mexicana, $B$. spectabilis and L. tridentata. For their part, Ye et al., 2014, found that extracts of four Chinese herbs Phellodendri chinensis, Artemisia annua, Scutellaria baicalensis and Citrus reticulate showed strong algaecidal effects when found coexisting with $M$. aeruginosa, even showing synergistic effects when binary mixtures of the aqueous extracts were made. 
The $\mathrm{EC}_{50}$ values can give an idea of the degree of efficacy of an extract on a certain species of cyanobacteria and can vary significantly depending on factors such as the plant species and its geographical origin, the plant part used and its age, the solvent used in the extraction, the concentration of the extract, the exposure time and the target cyanobacteria species, among others. In our research, no significant difference was observed between the $\mathrm{EC}_{50}$ values of $A$. mexicana, $B$. spectabilis and $L$. tridentata, similar to what was found by Zhang et al., 2015 (Table 3). However, in the study by Ye et al., 2014, a significant difference was observed between Artemisia annua extract and Phellodendri chinensis and Scutellaria baicalensis extracts. In another investigation, the efficacy of ethyl acetate extract of Conyza canadensis was far superior to the ethanolic extract of Artemisia annua (Ni et al., 2011).

Table $3 \mathrm{EC}_{50}$ value of different plant extracts on $M$. aeruginosa 


\begin{tabular}{|c|c|c|c|}
\hline Plant & Solvent & $\mathrm{CE}_{50}(\mathrm{mg} / \mathrm{L})$ & Reference \\
\hline A. mexicana & Methanol & 24.47 & \multirow{3}{*}{ In our study } \\
\hline B. spectabilis & Methanol & 20.27 & \\
\hline L. tridentata & Methanol & 13.63 & \\
\hline Oenanthe javanica & Ethanol & 9.23 & Zhang et al., 2015 \\
\hline Acorus calamus & Hexane & 13.59 & Zhang et al., 2015 \\
\hline Phellodendri chinensis & Water & 0.87 & Ye et al., 2014 \\
\hline Scutellaria baicalensis & Water & 0.88 & Ye et al., 2014 \\
\hline Artemisia annua & Water & 11.16 & Ye et al., 2014 \\
\hline Citrus reticulate & Water & 5.27 & Ye et al., 2014 \\
\hline Conyza canadensis & Ethyl acetate & 31.5 & Ni et al., 2011 \\
\hline Conyza canadensis & Petroleum ether & 111.5 & Ni et al., 2011 \\
\hline Conyza canadensis & Ethanol & 250 & Ni et al., 2011 \\
\hline Erigeron annuus & Ethyl acetate & 24.3 & Ni et al., 2011 \\
\hline Erigeron annuus & Petroleum ether & 200 & Ni et al., 2011 \\
\hline Erigeron annuus & Ethanol & 95 & Ni et al., 2011 \\
\hline Artemisia annua & Ethyl acetate & 121 & Ni et al., 2011 \\
\hline Artemisia annua & Petroleum ether & 143 & Ni et al., 2011 \\
\hline Artemisia annua & Ethanol & 275 & Ni et al., 2011 \\
\hline Salvia miltiorrhiza & Ethyl acetate & 98.9 & Yi et al., 2012 \\
\hline Acorus tatarinowii & Chlorophorm & 102.5 & Yi et al., 2012 \\
\hline Salvia miltiorrhiza & Chlorophorm & 111.5 & Yi et al., 2012 \\
\hline Polyginum cuspidatum & Chlorophorm & 122.9 & Yi et al., 2012 \\
\hline Acorus tatarinowii & Petroleum ether & 130 & Yi et al., 2012 \\
\hline Phellodendron amurense & Petroleum ether & 157.8 & Yi et al., 2012 \\
\hline
\end{tabular}

Chl-a is an essential photosynthetic pigment that serves for the uptake of light energy and its subsequent transformation to biochemical energy, therefore, the concentration of Chl-a is intimately related to the growth and photosynthetic activity of cyanobacteria (Chen et al., 2019). When $M$. aeruginosa cells were exposed to varying concentrations of $L$. tridentata extract, their Chl-a content decreased significantly, being consistent with the decrease in cell density, so we speculate that one of the mechanisms of action 
of this species on $M$. aeruginosa is the destruction of the photosynthetic system. Similar degradation was observed by Chen et al., 2019, when analyzing the flavonoids quercetin and luteolin isolated from pomegranate peel. In another report, Mowe et al., 2019, observed that the emergent macrophytes Ludwigia adscendens and Persicaria barbata significantly decreased Chl-a concentrations in a phytoplankton community dominated by different species of cyanobacteria and that increasing the density of $L$. adscendens and $P$. barbata resulted in a shift from cyanobacteria-dominated communities to green algae-dominated communities.

MDA is one of the most important products of membrane lipid peroxidation, so it can indirectly inform the degree of oxidative damage to the cyanobacterial membrane system induced by reactive oxygen species (ROS) (Chen et al, 2019; Zhu et al., 2021). In our study, L. tridentata extract dramatically increased the MDA content in $M$. aeruginosa. This suggests that the allelochemicals present in L. tridentata extract severely damaged the membrane integrity of $M$. aeruginosa leading to cell death. Our findings are in agreement with those reported by Li et al., 2016, when they observed that the aqueous extract of Sagittaria trifolia caused severe damage to the structure of $M$. aeruginosa cell membranes, increasing the MDA content 2.7-fold compared to the control. On the other hand, Zhang et al. (2011), found that aqueous extract of Thalia dealbata roots increased MDA content in M. aeruginosa up to 5.1 -fold compared to the control. In another study, Meng et al. (2015), reported that MDA content in M. aeruginosa about 2.3-fold due to exposure to ethanolic extract of Ailanthus altissima for 5 days. In addition, it significantly decreased the Chl-a content, proteins and superoxide dismutase (SOD) activity.

A consequence of lipid peroxidation is the leakage of intracellular material, such as proteins, DNA and RNA, among others (Zhang et al., 2012). In the present investigation, we observed a substantial increase in the protein and nucleotide concentration of $M$. aeruginosa due to exposure to $L$. tridentata extract, inducing gradual increases in $\mathrm{OD}_{280}$ and $\mathrm{OD}_{260}$ values. These findings allow us to propose that $L$. tridentata extract irreversibly damages the cell membrane of $M$. aeruginosa. Our results are similar to those described by Zhang et al., 2012, reporting the extract of Hydrilla verticillata caused an increase in protein and nucleotide concentration in Anabaena flos-aquae, being almost double compared to the control. In another study published by Zhang et al., 2010, they observed that the phenolic acids pcoumaric acid and vanillic acid caused the release of nucleic acids in $M$. aeruginosa, approximately 1.6 times more compared to the control.

\section{Conclusions}

This is the first study to test the algaecidal effects in solid and liquid media of four plant species commonly used in mexican traditional medicine. A. mexicana and B. spectabilis species showed significant effects on the growth of $M$. aeruginosa. However, L. tridentata presented the highest degree of effectiveness, due to its high polyphenol content. There is a positive correlation between the decrease in Chl-a content and the increase in the MDA content, proteins and nucleotides, so it is very likely that lipid peroxidation and damage to photosynthetic activity are among the main mechanisms of action of this species against $M$. aeruginosa. Because of the above, these species may be a source of effective 
algaecidal compounds to mitigate toxic cyanobacterial blooms. Future studies should be conducted to identify and quantify the allelochemicals present in extracts of L. tridentata, B. spectabilis and $A$. mexicana and study their effects on $M$. aeruginosa and other toxic cyanobacterial species.

\section{Declarations}

Acknowledgements: The authors acknowledge PhD Pedro Ramírez García for the contribution of the $M$. aeruginosa species and for the use of the Bacteriology Laboratory facilities. To PhD David Chicalote Castillo for his support in the cultivation of $M$. aeruginosa and the inhibition tests in solid medium.

Ethics approval and consent to participate: Not applicable.

Consent to publish: Not applicable.

Availability of data and materials: The datasets used and/or analysed during the current study are available from the corresponding author on reasonable request.

Conflict of interest: The authors declare that they have no competing interests.

Funding: This research was supported by the Graduate Sub-coordination of Mexican Institute of Water Technology. The Graduate Sub-coordination did not participate in this research.

Authors' contributions: RSJ participated in the conception and design of the study, carried out the preparation of the material, the quantification of total polyphenols, the algaecide tests in solid and liquid medium, the collection and analysis of data and made the first draft of the manuscript. SEGH contributed to the conception and design of the study, purchased the reagents and materials, provided the UV-Vis equipment, arranged the loan of the cyanobacterium $M$. aeruginosa, and provided comments on the draft. AMSV participated in the conception and design of the study, provided the methodologies for the culture of $M$. aeruginosa and for the quantification of Chl-a, MDA, proteins and nucleotides, helped the statistical analysis of the results and made comments on the first draft. MLV participated in the conception and design of the study, provided the freeze-drying and deep-freezing equipment, participated in the search and selection of the plant species and their identification, and provided comments on the first draft. JRVI contributed to the conception and design of the study, participated in the quantification of total polyphenols and in the analysis of the results and the discussion. All authors read and approved the final manuscript.

\section{References}

Abarca VR, Petricevich LV (2018) Bougainvillea genus: A review on phytochemistry, pharmacology, and toxicology. Evid Based Complement Alternat Med 2018:1-17. https://doi.org/10.1155/2018/9070927.

Arteaga S, Andrade CA, Cárdenas R (2005) Larrea tridentata (Creosote bush), an abundant plant of Mexican and US-American deserts and its metabolite nordihydroguaiaretic acid. J Ethnopharmacol 
Brahmachari G, Gorai D, Roy R (2013) Argemone mexicana: chemical and pharmacological aspects. Braz J Pharmacogn 23:559-575. https://doi.org/10.1590/S0102-695X2013005000021.

Chen L, Wang Y, Shi L, Zhao J, Wang W (2019) Identification of allelochemicals from pomegranate peel and their effects on Microcystis aeruginosa growth. Environ Sci Pollut Res 26:22389-22399. https://doi.org/10.1007/s11356-019-05507-1.

Ghobrial MG, Nassr HS, Kamil AW (2015) Bioactivity effect of two macrophyte extracts on growth performance of two bloom-forming cyanophytes. Egypt J Aquat Res 41:69-81. https://doi.org/10.1016/j.ejar.2015.01.001.

Ghogar A, Jiraungkoorskul K, Jiraungkoorskul W (2016) Paper Flower, Bougainvillea spectabilis: Update Properties of Traditional Medicinal Plant. J Nat Remedies 16:82-87. DOI: 10.18311/jnr/2016/5703.

Hein MK (2017) Part 10200 H. Chrorophyll. In: Baird RB, Eaton AD, Rice EW (eds) Standard methods for the examination of water and wastewater, 23rd edn. American Water Works Association, Washington, DC, pp 21-29.

Huisman J, Codd GA, Paerl HW, Ibelings BW, Verspagen JMH, Visser PM (2018) Cyanobacterial blooms. Nat Rev Microbiol 16:471-483. https://doi.org/10.1038/s41579-018-0040-1.

Kaminski A, Bober B, Chrapusta E, Bialczyk J (2014) Phytoremediation of anatoxin-a by aquatic macrophyte Lemna trisulca L. Chemosphere 112:305-310.

https://doi.org/10.1016/j.chemosphere.2014.04.064.

Kaminski A, Chrapusta E, Bober B, Adamski M, Latkowska E, Bialczyk J (2015) Aquatic macrophyte Lemna trisulca (L.) as a natural factor for reducing anatoxin-a concentration in the aquatic environment and biomass of cyanobacterium Anabaena flos-aquae (Lyngb.) de Bréb. Algal Research 9:212-217. https://doi.org/10.1016/j.algal.2015.03.014.

Li J, Liu Y, Zhang P, Zeng G, Cai X, Liu S, Yin Y, Hu X, Hu X, Tan X. (2016) Growth inhibition and oxidative damage of Microcystis aeruginosa induced by crude extract of Sagittaria trifolia tubers. J Environ Sci 43:40-47. https://doi.org/10.1016/j.jes.2015.08.020.

Mata BJM, Treviño GEJ, Alanís RE, Chávez CAC, Rubio CEA, Mora OA, Martínez AJG (2018) Structure and diversity of Larrea tridentata (DC.) Coville, microphyllus desert scrub in northeast mexico. Interciencia 43:449-454. https://www.interciencia.net/wp-content/uploads/2018/06/449-MATA-43_6.pdf. Accessed 7 June 2021.

Meng P, Pei H, Hu W, Liu Z, Li X, Xu H (2015) Allelopathic effects of Ailanthus altissima extracts on Microcystis aeruginosa growth, physiological changes and microcystins release. Chemosphere 141:219226. https://doi.org/10.1016/j.chemosphere.2015.07.057. 
Mowe MAD, Song Y, Sim DZH., Lu J, Mitrovic SM, Tan HTW, Yeo DCJ (2019) Comparative study of six emergent macrophyte species for controlling cyanobacterial blooms in a tropical reservoir. Ecol Eng 129:11-21. https://doi.org/10.1016/j.ecoleng.2018.12.026

Ni L, Acharya K, Hao X, Li S, Li Y, Li Y (2012) Effects of artemisinin on photosystem Il performance of Microcystis aeruginosa by in vivo chlorophyll fluorescence. Bull Environ Contam Toxicol 89:1165-1169. https://doi.org/10.1007/s00128-012-0843-0.

Ni L, Hao XY, Li SY, Chen SJ, Ren GX, Zhu L (2011) Inhibitory effects of the extracts with different solvents from three compositae plants on cyanobacterium Microcystis aeruginosas. Sci China Chem 54:11231129. https://doi.org/10.1007/s11426-011-4269-z.

Palma, TM, San Miguel CR, Soto HRM (2017) Aromatic and Medicinal Plants in Mexico. Chapter 7: Aromatic and medicinal plants in Mexico, In book: Aromatic and medicinal plants.

http://dx.doi.org/10.5772/66507.

Shi Y, Shen A, Tan M, He P, Shao L (2020) The effect of plant extracts on growth and photosynthetic fluorescence characteristics of Microcystis flos-aquae. Water Sci Technol 82:1102-1110.

https://doi.org/10.2166/wst.2020.312

Tan JB, Yap WJ, Tan SY, Lim YY, Lee SM (2014) Antioxidant content, antioxidant activity, and antibacterial activity of five plants from the Commelinaceae family. Antioxidants 3:758-769. https://doi.org/10.3390/antiox3040758.

Tan K, Huang Z, Ji R, Qiu Y, Wang Z, Liu J (2019) A review of allelopathy on microalgae. Microbiology 165:587-592. https://doi.org/10.1099/mic.0.000776.

Tebaa L, Douma M, Tazart Z, Manaut N, Mouhri K, Loudiki M (2017) Algicidal effects of Achillea ageratum L. and Origanum compactum Benth. plant extracts on growth of Microcystis aeruginosa. Appl Ecol Environ Res 15:719-728. Doi: 10.15666/aeer/1504_719728.

Tazart Z, Douma M, Tebaa L, Loudiki M (2018) Use of macrophytes allelopathy in the biocontrol of harmful Microcystis aeruginosa blooms. Water Supply 19:245-253.

https://doi.org/10.2166/ws.2018.072.

Villaseñor JL (2016) Checklist of the native vascular plants of Mexico. Rev Mex Biodivers 87:559-902. http://dx.doi.org/10.1016/j.rmb.2016.06.017.

Wang H, Liang F, Zhang L (2015) Composition and anti-cyanobacterial activity of essential oils from six different submerged macrophytes. Pol J Environ Stud 24:333-338.

https://doi.org/10.15244/pjoes/26383.

Wang X, Jiang C, Szeto Y, Li H, Yam KL, Wang X (2016) Effects of Dracontomelon duperreanum defoliation extract on Microcystis aeruginosa: physiological and morphological aspects. Environ Sci 
Pollut Res 23:8731-8740. https://doi.org/10.1007/s11356-016-6119-1.

Yan D, Xu H, Lan J, Yang M, Hou W, Zhou K, An Z (2020) Warming favors subtropical lake cyanobacterial biomass increasing. Sci Tot Environ 726:1-7. https://doi.org/10.1016/j.scitotenv.2020.138606.

Ye L, Qian J, Jin S, Zuo S, Mei H, Ma S (2014) Algicidal effects of four Chinese herb extracts on bloomforming Microcystis aeruginosa and Chlorella pyrenoidosa. Environ Technol 35:1150-1156. doi: 10.1080/09593330.2013.863979.

Yi YL, Lei Y, Yin YB, Zhang HY, Wang GX (2012) The antialgal activity of 40 medicinal plants against Microcystis aeruginosa. J Appl Phycol 24:847-856. https://doi.org/10.1007/s10811-011-9703-2.

Zerrifi SEA, Tazart Z, Khalloufi FE, Oudra B, Campos A, Vasconcelos V (2019) Potential control of toxic cyanobacteria blooms with Moroccan seaweed extracts. Environ Sci Pollut Res 26:15218-15228. https://doi.org/10.1007/s11356-019-04921-9.

Zhang C, Ling F, Lei YY, Yu ZH, Xue WG (2013a) Algicidal activity and potential mechanisms of ginkgolic acids isolated from Ginkgo biloba exocarp on Microcystis aeruginosa. J Appl Phycol 26:323-332. https://doi.org/10.1007/s10811-013-0057-9.

Zhang C, Yi Y, Hao K, Liu G, Wang G (2013b) Algicidal activity of Salvia miltiorrhiza Bung on Microcystis aeruginosa-Towards identification of algicidal substance and determination of inhibition mechanism. Chemosphere 93:997-1004. https://doi.org/10.1016/j.chemosphere.2013.05.068.

Zhang SH, Guo L, Cao JY, Chang JJ (2015) Allelopathic activities of three emergent macrophytes on several monospecific cyanobacterial species and natural phytoplankton assemblages. Pol J Environ Stud 24:397-402. https://doi.org/10.15244/pjoes/26972.

Zhang TT, He M, Wu AP, Nie LW (2012) Inhibitory Effects and Mechanisms of Hydrilla verticillata (Linn.f.) Royle Extracts on Freshwater Algae. Bull Environ Contam Toxicol 88:477-481. https://doi.org/10.1007/s00128-011-0500-z

Zhang TT, Wang LL, He ZX, Zhang D (2011) Growth inhibition and biochemical changes of cyanobacteria induced by emergent macrophyte Thalia dealbata roots. Biochem Syst Ecol 39:88-94. https://doi.org/10.1016/j.bse.2011.01.004.

Zhang TT, Zheng CY, Hu W, Xu WW, Wang HF (2010) The allelopathy and allelopathic mechanism of phenolic acids on toxic Microcystis aeruginosa. J Appl Phycol 22:71-77. https://doi.org/10.1007/s10811-009-9429-6.

Zhu X, Dao G, Tao Y, Zhan X, Hu H (2021) A review on control of harmful algal blooms by plant-derived allelochemicals. J Hazard Mater 401: 123403. https://doi.org/10.1016/j.jhazmat.2020.123403. 


\section{Figures}

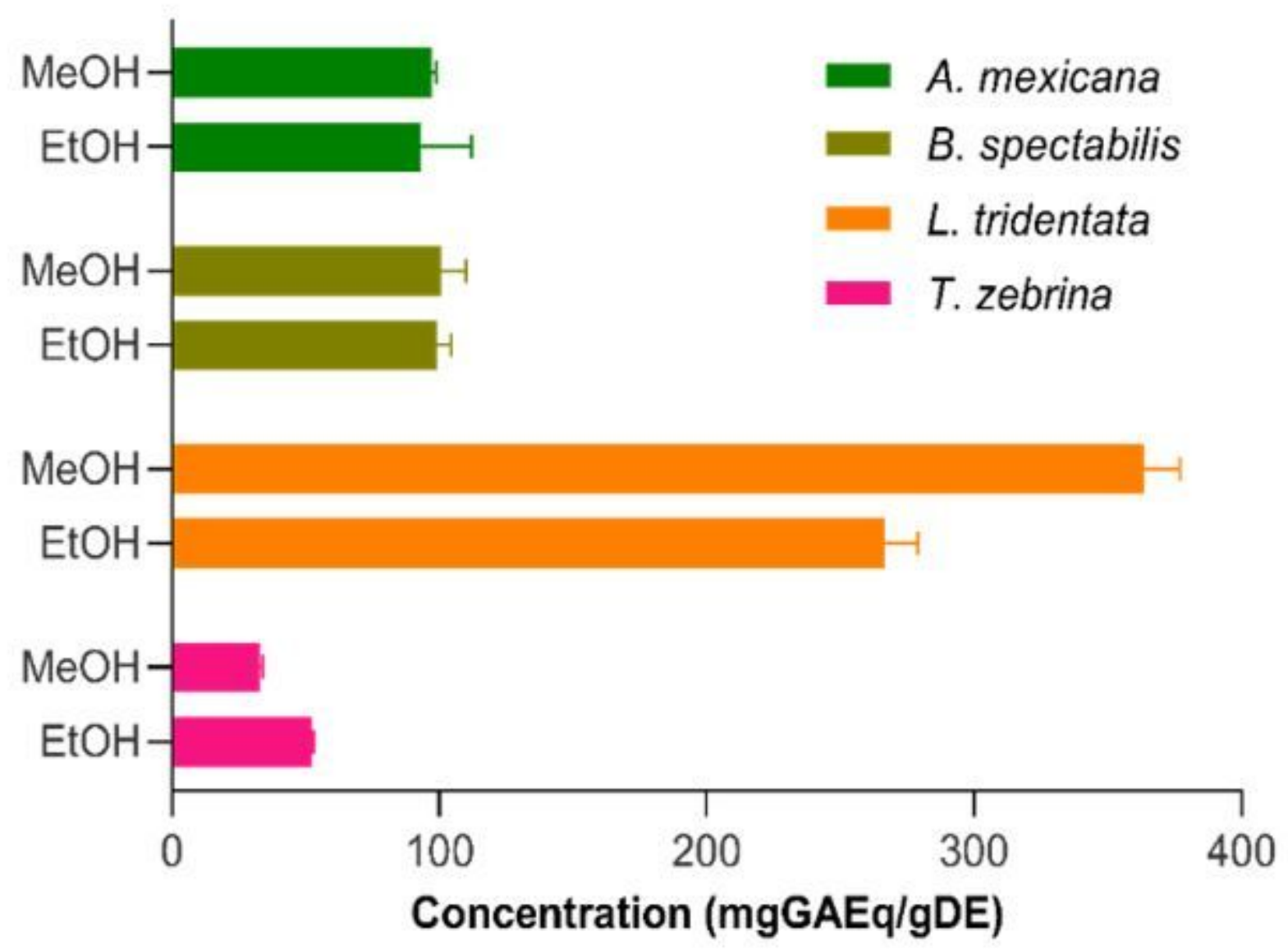

Figure 1

Total polyphenolic compounds in ethanolic and methanolic extracts of plant species
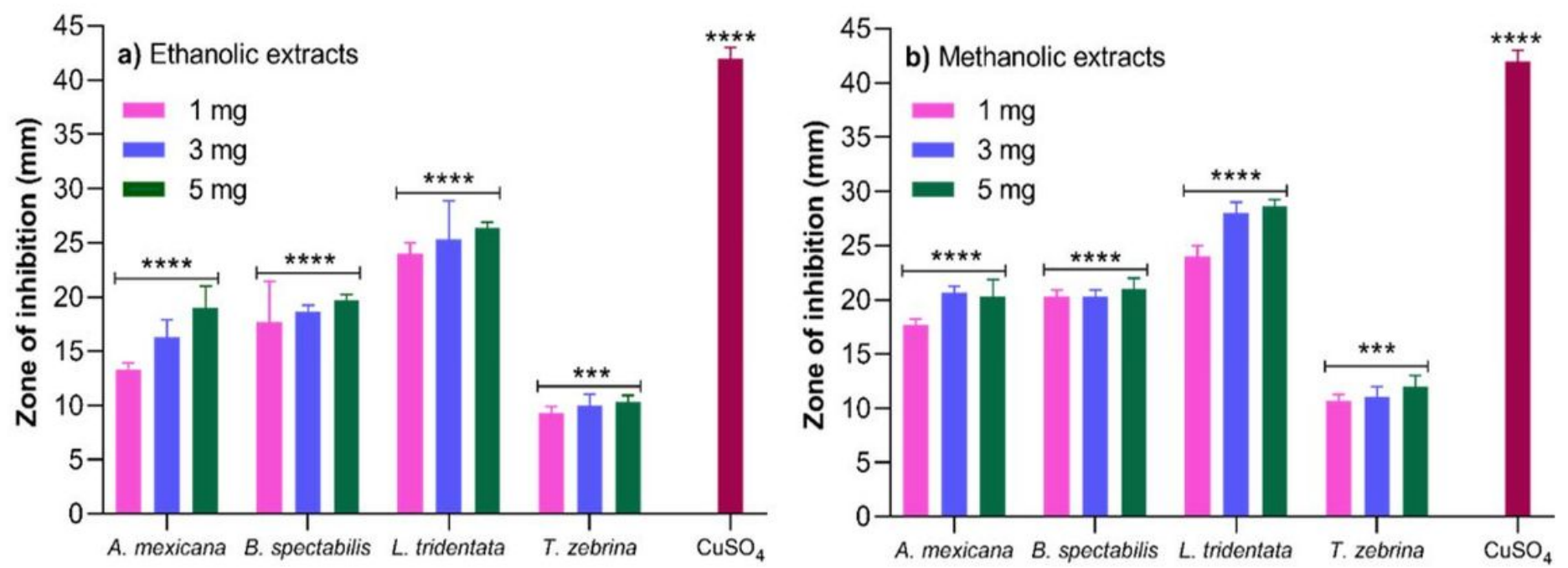

Figure 2 
Antiagal activity of the extracts against $\mathrm{M}$. aeruginosa measured as the diameter of the zone of inhibition
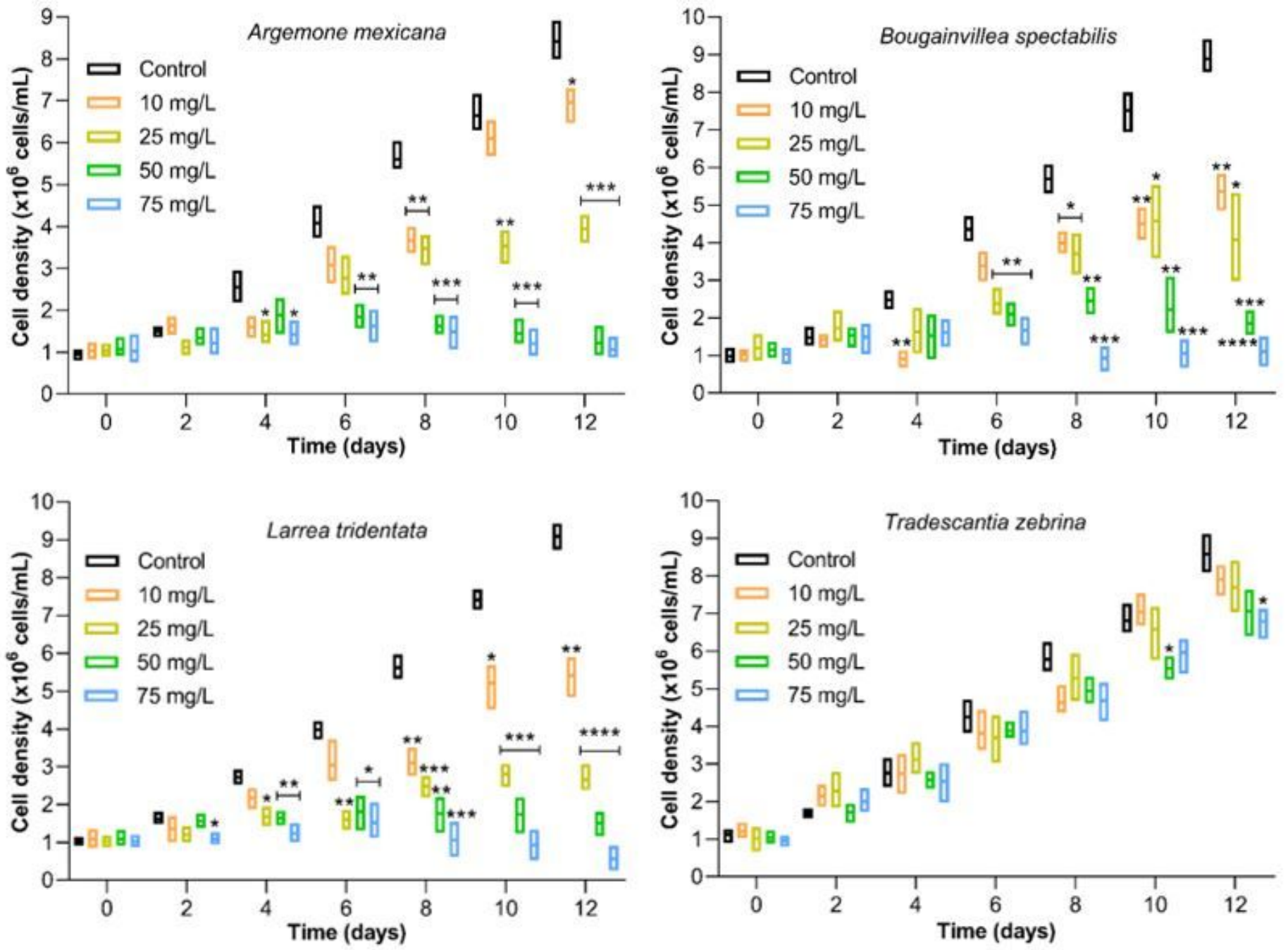

Figure 3

Effects of methanolic extracts on the cell density of M. aeruginosa 

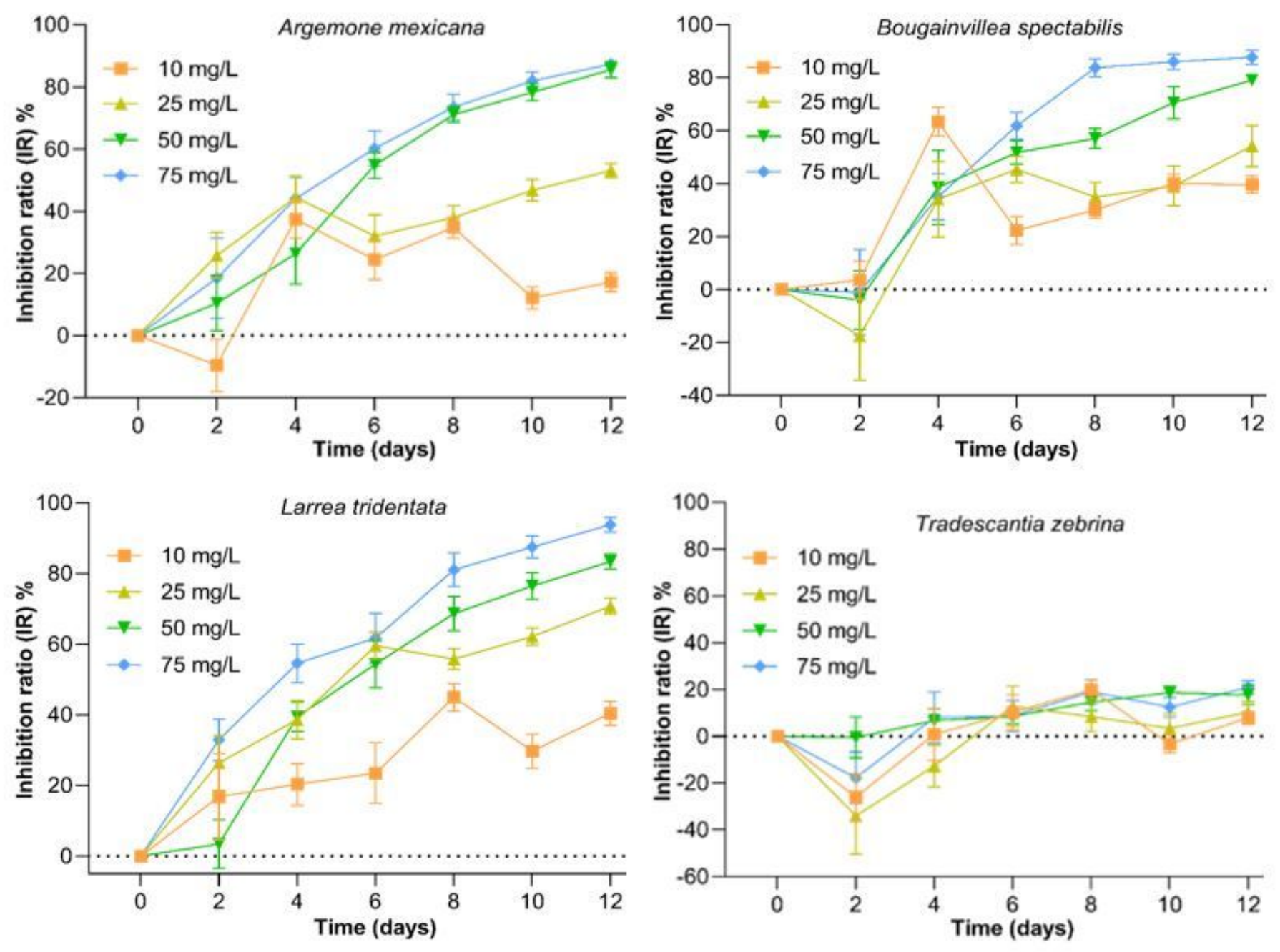

Figure 4

Inhibitory rates of methanolic extracts on $\mathrm{M}$. aeruginosa 

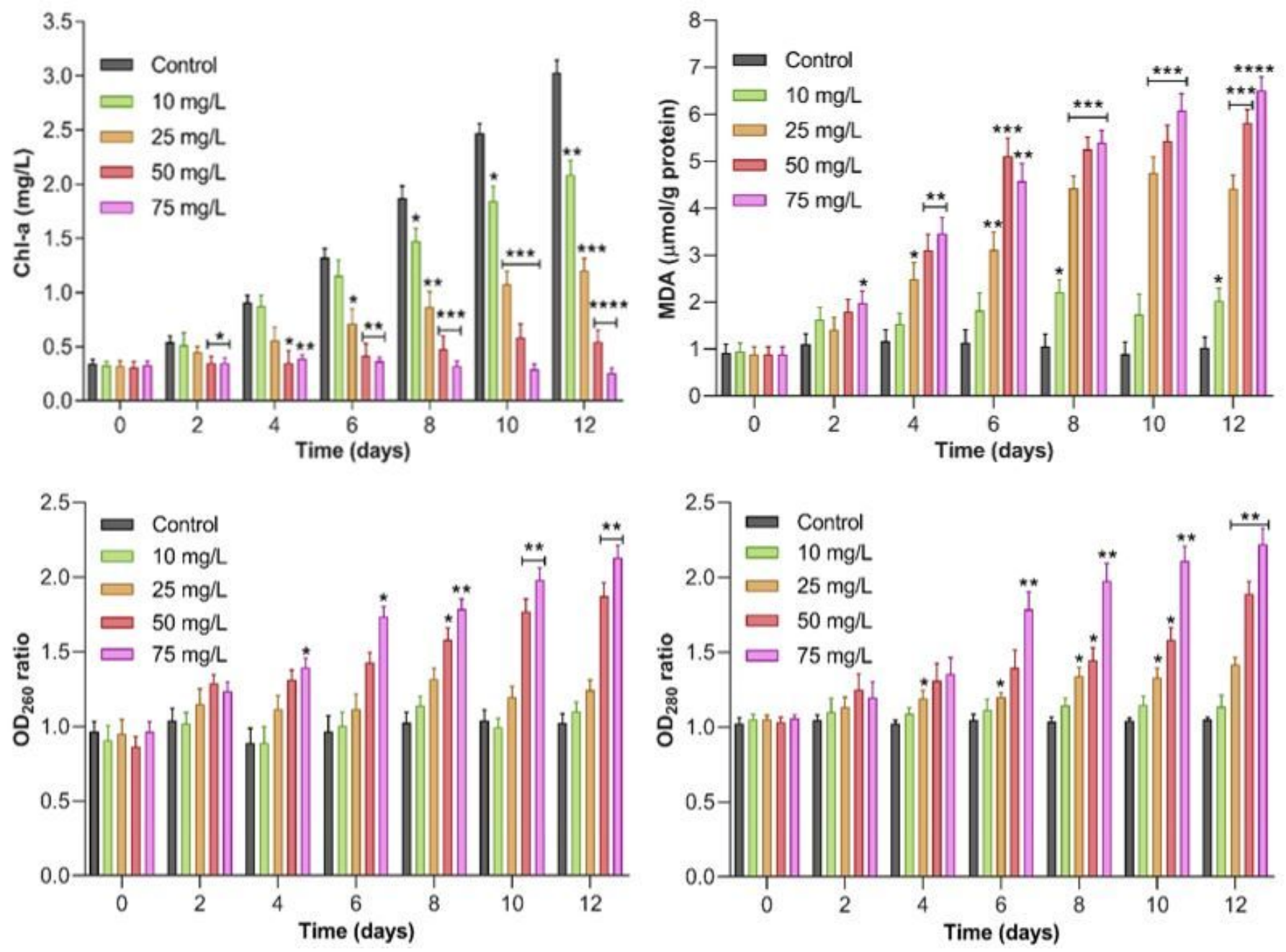

Figure 5

Effects of L. tridentata extract on the content of Chl-a, MDA, nucleotides and proteins in M. aeruginosa 